\title{
WHAT STUDENTS IN THE FIRST GRADES OF ELEMENTARY SCHOOL KNOW ABOUT TABLES
}

\author{
GILDA GUIMARÃES \\ Universidade Federal de Pernambuco \\ gilda.lguimaraes@gmail.com \\ BETÂNIA EVANGELISTA \\ Prefeitura Municipal de Olinda and Governo do Estado de Pernambuco \\ mbevangelista@hotmail.com \\ IZABELLA OLIVEIRA \\ Université Laval \\ izabella.oliveira@fse.ulaval.ca
}

\begin{abstract}
The definition of table has not been introduced in Brazilian textbooks for the early years of elementary school. We see that charts and databases have been named but tables are not approached in the same way. This makes it impossible for students to differentiate between them, which may cause learning difficulties. Therefore, it is essential that we reflect on students' knowledge about a table, which is an instrument that systematizes information so that they can visualize reality. Thus, the aim of this study was to analyze the knowledge students from the 1st to 5 th grade of elementary school have about representations in tables. To this end, 325 students ( 6 to 10 years old from 19 classes from different public schools in Greater Recife) participated. Students were asked to answer six activities individually, four of interpretation of a single and a double entry table with qualitative and quantitative variables, and two activities involving the construction of a table from a database or set of figures that needed to be classified. The results show that students' performance progresses in all activities, and that they present better performance in table interpretation than in table construction. Since the $1^{\text {st }}$ grade the students were able to construct tables with one variable; however, to construct a table with two variables proved to be very difficult even for the $5^{\text {th }}$ graders. In all grades the students had difficulties in making decisions based on the data presented and understanding the function of table representations. This may be due to the absence of teaching practices that focus on the table as a learning object.
\end{abstract}

Keywords: Statistics education research; Primary school; Learning; Tables

\section{INTRODUCTION}

The social transformations and technological advances that have taken place in society these days have made it possible for people to increase the use of statistical information in their daily lives. Graphs and tables, among other tools, are used to disseminate research of various interests. Thus, a citizen is expected to be able to interpret them, construct them and make inferences based on them, to be able to make conscious decisions in the face of statistical situations.

According to Gal (2002), to be considered statistically literate, people need to know statistical concepts and ideas and put them into practice when seeking to understand social events. In many situations, people are led to analyze information used by the media that sometimes does not reflect reality, and the statistical terms used may be related to different meanings, which may generate ambiguous, confusing, or misleading statistical information. In this perspective, several authors defend a statistical education based on research (e.g., Wild \& Pfannkuch, 1999; Silva \& Guimaraes, 2013; Guimarães \& Gitirana, 2013; Gitirana, 2014, Guimarães \& Oliveira, 2014). Therefore, schools should provide students with an education that can contribute to their full potential in society, enabling them to act reflexively, thoughtfully, and critically. 
In Brazil, as from 1997, the National Curriculum Parameters (Brasil, 1997), and later the Common National Curriculum Base (BNCC in Portuguese), have emphasized the importance of learning statistical concepts from the early years of elementary school (Brasil, 2017). The objective of the BNCC for the 1st grade of elementary school is to interpret data represented in tables; moving to the differentiation between single and double entry tables using terms such as higher and lower frequency; and procedures that involve data collection, classification, and representation in tables with categorical and numerical variables, with or without the use of digital technologies that lead to the production of text with conclusions. Thus, as the years of schooling progress, new elements are introduced, such as the type of table and variable, the number of elements to be collected in a research project, and how to represent the data collected.

However, although important, such attributions are not well worked and/or learned, because, according to the Functional Literacy Indicator (INAF, 2011, 2016), only 8\% of the Brazilian population are proficient in understanding and interpreting graphs and tables involving more than two variables. Similarly, studies about children also reveal that they have difficulties with table representation (Febles \& Guerra, 2009; Giot \& Quittre, 2008; Guimarães, 2009; Martí et al., 2010; Conti \& Carvalho, 2011; Bivar \& Selva, 2013; Pagan et al., 2013; Díaz-Levicoy et al., 2017).

Estrella (2014) stated that the ability to analyze information represented in tables is an important aspect for scientific culture and requires explicit attention at all levels of education. There is, however, little research on how students learn to construct and interpret tables of statistical data (Pfannkuch \& Rubick, 2002). It appears understanding how to construct tables requires a more sophisticated skill than researchers previously thought. The ability to interpret information in tables is not acquired by exposing the subject to students, this acquisition occurs through intentional and systematic work, aimed at generating discussions and reflections on the functionality and importance of representations (Conti \& Carvalho, 2011; Guimarães \& Oliveira, 2014). For this, it is necessary to consider the need to know how to classify the elements of tables based on one or more criteria and to understand the graphic specificities of this type of representation.

One factor that could explain the difficulties of the students to understand tables is the lack of systematic work in schools, which may have led students to exhibiting misunderstandings. It is noteworthy that teachers were also found to show similar misunderstandings (Luz, 2011; Oliveira \& Guimarães, 2012; Bianchini \& Nehring, 2013; Dessbesel \& Cury, 2013; Santos, 2016). Another factor is the absence of greater quantity and quality of activities with tables in textbooks. When present, tables are not explored as a mathematical object (Guimarães et al., 2007; Pereira \& Conti, 2011; Bivar \& Selva, 2011; Curi \& Nascimento, 2016; Amorim \& Silva, 2016; Amorim, 2017; Evangelista \& Guimarães, 2019). In consideration of these points, this research aims to analyze what students in the early years of elementary school know about representation in tables.

\subsection{REPRESENTATION IN TABLES}

For Martí et al. (2010), the table was an indispensable tool for many cognitive - and especially scientific - tasks. Its form allows you to display information in an orderly manner, according to the intersection of variables, to infer and calculate new values easily (the sum of a column or row, the identification of empty cells, knowing the highest or lowest value in a column/row, among others). Estrella (2014) stated that, historically, the exploration of tables was related to different situations (data storage instrument, calculation, measurements, among others) and followed both the historical progress and the social needs. Today tables are also mathematical objects. Thus, we can observe that tables play a double role, as a tool and as an object of knowledge.

Duval (2003) and Giot and Quittre (2008) argued that not all tables are the same; there is a range of types of tables, and their various readings require different cognitive resources. The term "table" is used for many things, for example, computational tables, such as the multiplication table; mnemotechnic tables, such as the periodic table of chemical elements; and heuristic tables, such as the logarithmic table. Tables have their own complete and straightforward way to present information. Therefore, it is necessary that the students are taught how to understand those different types of representations.

Guimarães and Oliveira (2014) argued that teaching tables should allow students to understand better what is being represented, so that they can make inferences on the information they contain. To this end, it is important for teachers to offer a variety of activities with tables that enable students to 
learn how to both represent data contained in tables and build tables to organize data. However, we came across different types of representations in textbooks with rectangular configurations such as quadro, database and tables that, although having visual similarities, that is, rectangular configurations divided into rows and columns, display and treat the data in different ways. Please note, the Portuguese word "quadro" has no English translation. Thus, in this article we will keep the word in Portuguese since differentiating it from "table" is very important for our argument as described and exemplified throughout the text. Thus, students must read and interpret those representations from different points of view for a true understanding of the information exposed.

Quadro is defined as a rectangular configuration with rows and columns that do not express variables. They are graphical ways of organizing texts and operations spatially (Figure 1). A representation in a database is a rectangular configuration with rows and columns. In the rows, we have each of the elements, and in the columns, the variables that describe each element. The information is presented based on individual registers, in which it is possible to recognize the characteristics by data displayed (Figure 2).

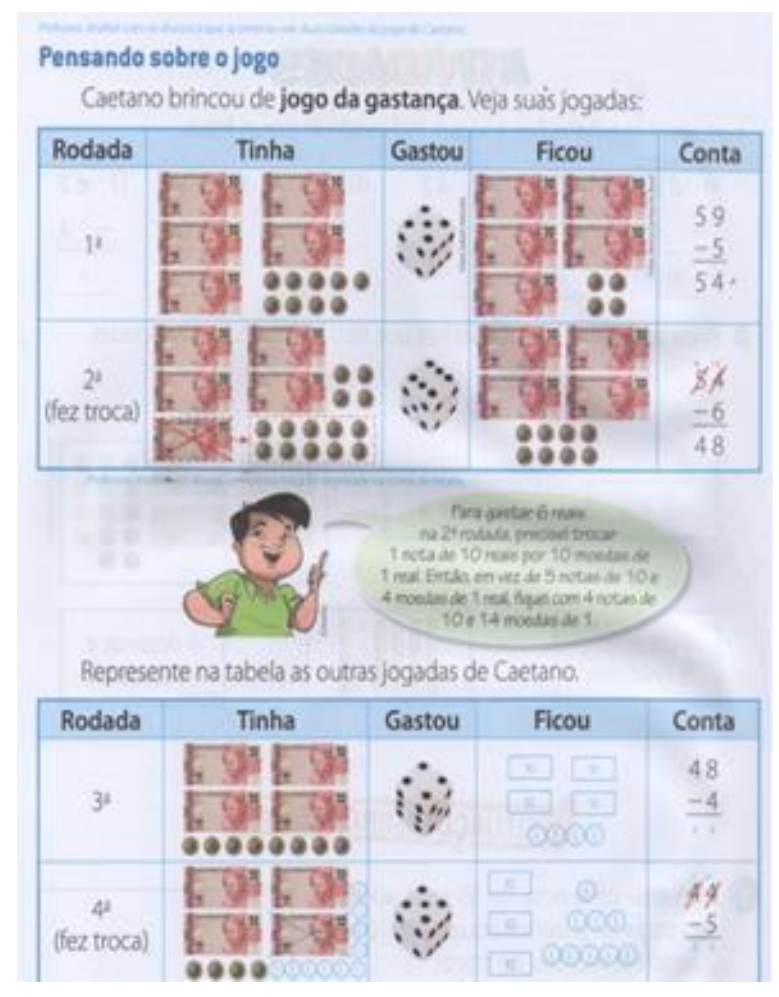

Figure 1. Representation in Quadro

Source: Coleção $E-3^{\circ}$ ano (p. 135)

[In this activity, the student is requested to solve the operation of adding banknotes and coins.]

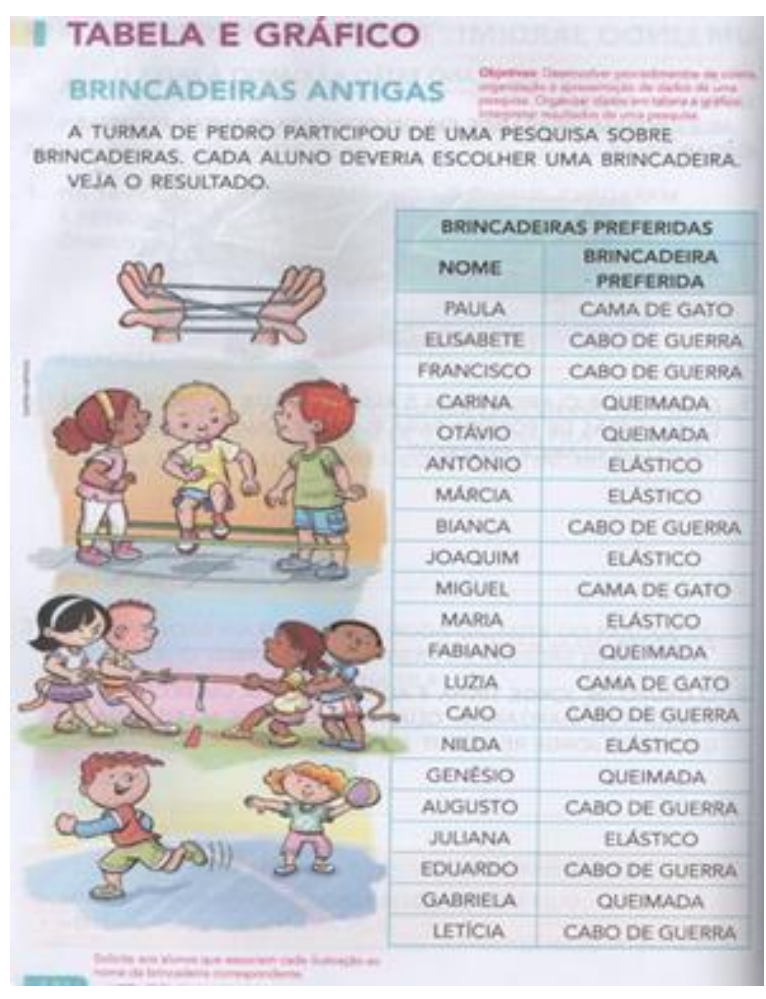

Figure 2. Representation in a database Source: Coleção $B-1^{\circ}$ ano (p. 55)

[The database shows the names of children and their favorite games.]

Finally, as Cazorla et al. (2017) defined, a frequency distribution table (FDT) is a rectangular configuration with rows and columns, which is a type of statistical table formed by the categories ordered or not (qualitative variable), specific values (discrete variable) or intervals (continuous variable) and their absolute or relative frequency. An example is presented in Figure 3. 


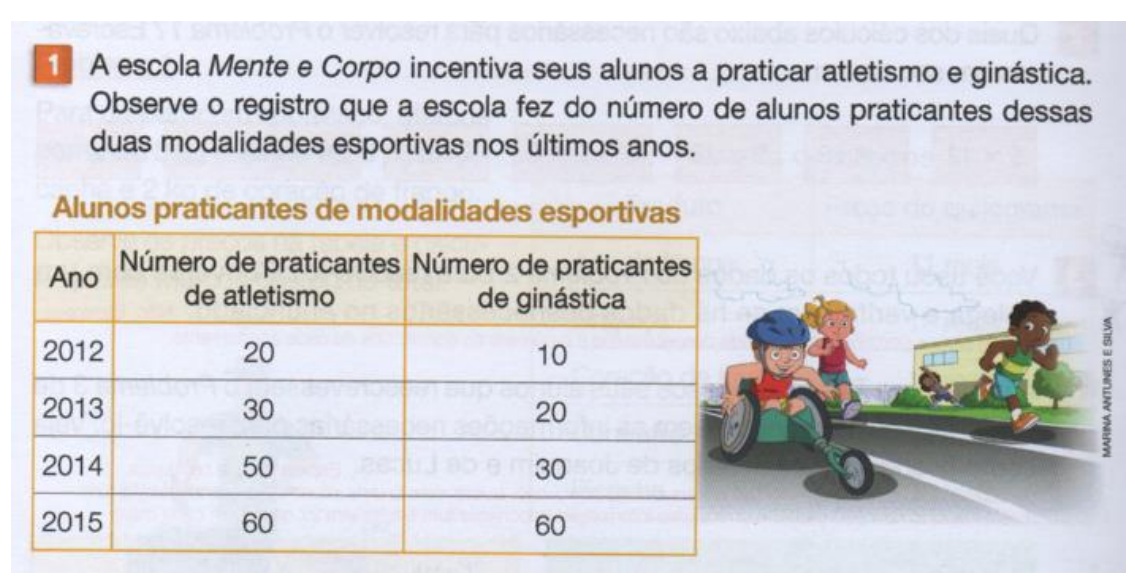

\begin{abstract}
Figure 3. Representation in a table
Source: Coleção D $-4^{\circ}$ ano (p. 126)

[The table shows the number of students who practice sports (athletics and gymnastics) per year, from 2012 to 2015]
\end{abstract}

\title{
1.2. TEACHING TABLES
}

In the literature, several authors address the use and teaching of tables in different years of schooling. Many studies, however, have revealed that tables have been used predominantly as tools to assist teaching other mathematical contents (Guimarães et al., 2007; Pereira \& Conti, 2011; Bivar \& Selva, 2013; Curi \& Nascimento, 2016; Amorim \& Guimarães, 2017; Estrella, Mena-Lorca \& Olfos, 2017; Díaz-Levicoy et al., 2017; Evangelista \& Guimarães, 2019).

Sharma (2013) states that, on one hand, it can be easy to teach students to extract simple information from tables. On the other hand, it is difficult for students to make comparisons within and between categories, and to think about the meaning of the data. In fact, addressing questions involving "issues of opinion" or interpreting general ideas presented in tables have been poorly taught, as the studies by Guimarães (2002), Lobo and Alcântara (2011), Estrella (2014), and Nope et al. (2015) highlight.

For both Duval (2003) and Giot and Quittre (2008), the apparent simplicity of the table misleads people's reading, because they believe that there is only one way to interpret them. However, there are different types of tables, and they must be analyzed in different ways. In their studies, Jungkenn and Del Pino (2009), Lobo and Alcântara (2011), Lima and Viali (2013), Francisco (2014), and Nope et al. (2015) reported students' failure in interpreting information in tables. This is quite worrying, because Gal (1996) stated that students should be led to raise questions, communicate opinions, and evaluate data as these behaviors are the gateway to students' reasoning about the data.

When analyzing how tables have been presented, it is observed that there are inadequacies regarding their teaching, which may occur in the form of conceptualizing, classifying and/or presenting tables. Issues also arise in the choice and management of activities to be worked with the students, as argued by Guimarães and Oliveira (2014). This situation may be due to the teachers' lack of familiarity with the table, which makes them feel incapable of working properly with this statistical element, as evidenced by Oliveira and Guimarães (2012), Bianchini and Nehring (2013), Dessbesel and Cury (2013), and Santos (2016). For Giot and Quittre (2008), although tables have been used in the classroom, reflective practice about their implementation are rarely observed. According to Martí et al. (2010), the construction of tables has not been an explicit object of instruction for students, neither presented in textbooks activities nor in the practices of their teachers.

Considering those studies, we determined that it was necessary to investigate, based on the same instrument, students' understanding of tables in different grades of elementary school, whether their knowledge evolves during schooling, and how this evolution occurs. Therefore, the objective of this research was to analyze the knowledge about interpreting and constructing tables by students from $1 \mathrm{st}$ to 5 th grade of some Brazilian elementary public school (6 to 10 years old). 


\section{METHOD}

The study included 325 students from 1st to 5th grade of elementary school (66, 64, 60, 67, 68 students, respectively), who attended 19 (nineteen) classes from the early grades of elementary school in municipal schools in the metropolitan region of Recife/Pernambuco (Brazil).

Based on the ideas defended in the different studies mentioned above and the studies by Evangelista and Guimarães $(2017 ; 2019)$, which aimed to discuss and reflect on the importance of teaching tables as a learning focus, a diagnostic test was developed involving real data from different situations that explored the representation in tables. The test comprised of six questions, four of which were on interpretation in single or double entry tables, and two questions on table construction, which were based on different supports: database and elements to be classified.

Questions of interpretation always had the same pattern: a) locating a lower frequency cell; b) locating a frequency cell from a category; c) locating category cells from a frequency; d) decisionmaking based on the data with justification (e.g., Figure 4, Questions d. A school that caters for 5-10 year-olds wants to buy new books for the library. Looking at this table, what kind of book would be best to buy? Why?). Questions 1 and 2 involved single tables (Figures $4 \& 5$ ) and Questions 3 and 4 , double entry tables (Figures $6 \&$ 7), Questions 1 and 3 involved nominal variables and Questions 2 and 4 involved numerical variables. Question 5 involved building a table from a two-variable database (Figure 8), and Question 6 involved creating a criterion to classify 15 elements and constructing a table with that information (Figure 9).

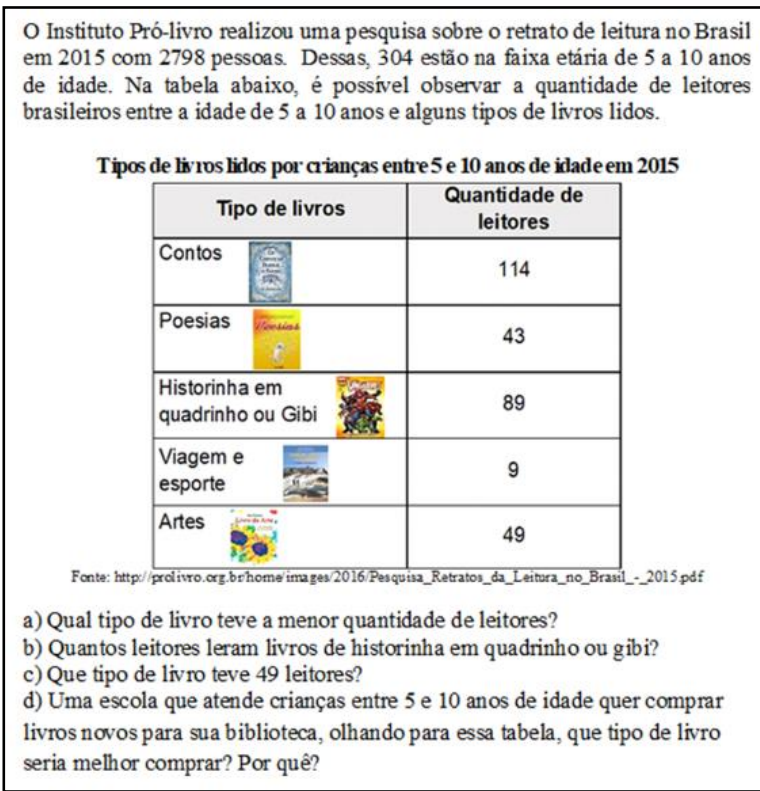

Figure 4. Question 1: Interpretation in single table with nominal qualitative variable. [Book types by number of readers.]
A tabela abaixo apresenta um levantamento realizado pelo CEMIT sobre o número de vítimas de ataques de tubarões nas praias pemambucanos no período de 25 anos. Observa-se a quantidade de vítimas a cada período de 5 anos.

Número devitimas de ataques de tubarões naspraias pernambucanas em periodos de 5 anos

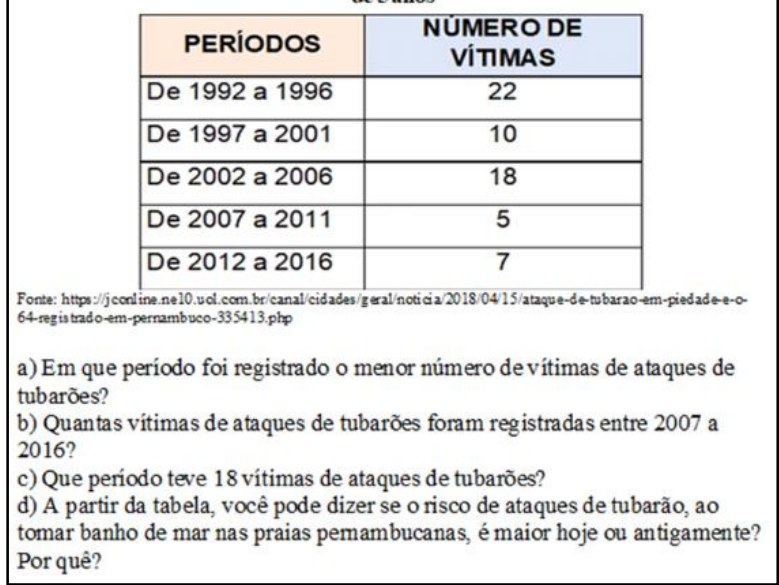

Figure 5. Question 2: Interpretation in single table with interval quantitative variable.

[Periods by number of victims of shark attack.] 


\begin{tabular}{|c|c|c|}
\hline \multicolumn{3}{|c|}{$\begin{array}{l}\text { Abaixo temos uma tabela que mostra a quantidade de cartões amarelos e } \\
\text { vermelhos recebidospor algumas seleçðesna fase de grupo nas últimas } 5 \text { copas } \\
\text { do mundo de futebol FIFA. }\end{array}$} \\
\hline \multicolumn{3}{|c|}{$\begin{array}{l}\text { Quantidade de cartões recebidos pelas seleçōes na fase de grupo (fase inirial) nas } \\
\text { últimas } 5 \text { copas do mundo de futebolFIFA }\end{array}$} \\
\hline \multirow{2}{*}{ SELEÇĀO } & \multicolumn{2}{|c|}{ TIPODE CARTÃO } \\
\hline & AMARELO & VERMELHO \\
\hline França & 28 & 1 \\
\hline Brasil $\theta$ & 20 & 1 \\
\hline Espanha $\frac{3}{3}$ & 18 & 0 \\
\hline Alemanha & 30 & 2 \\
\hline Itália & 27 & 2 \\
\hline \multicolumn{3}{|c|}{ 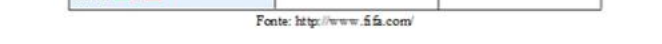 } \\
\hline \multicolumn{3}{|c|}{$\begin{array}{l}\text { a) Que seleção recebeu o menor número de cartões amarelos? } \\
\text { b) Quantos cartões vermelhos a seleção Alemã recebeu? } \\
\text { c) Que seleção recebeu } 27 \text { cartões amarelos? } \\
\text { d) De acordo com a tabela, qual dessas seleções tem mais chances de ganhar } \\
\text { um prêmio, no futuro, por apresentar um futebol mais limpo, ou seja, com } \\
\text { menos faltas? Por quê?? }\end{array}$} \\
\hline
\end{tabular}

Figure 6. Question 3: Interpretation in double entry table with nominal qualitative variables [Number of cards received by the teams in the group stage (initial phase) in the last 5 FIFA World Cups.]

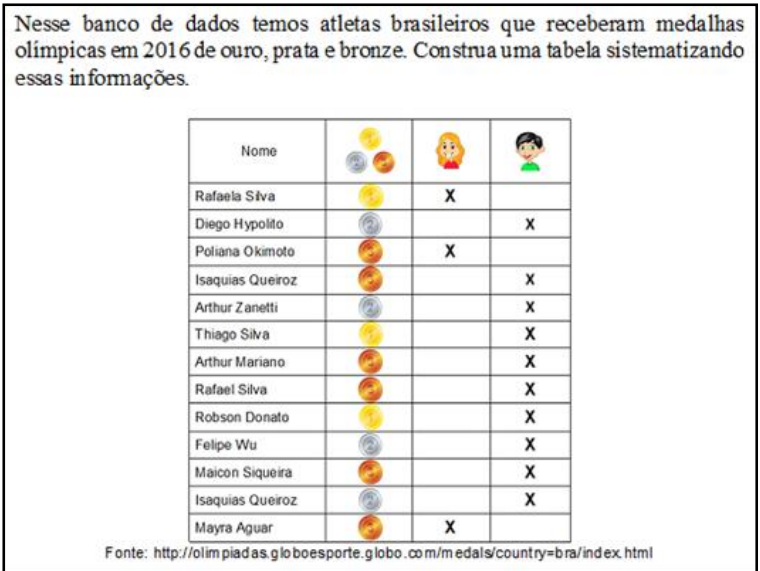

Figure 8. Question 5: Building a double entry table-based database

[In this database we have Brazilian athletes who received 2016 Olympic gold, silver and bronze medals. Build a table by systematizing this information.]

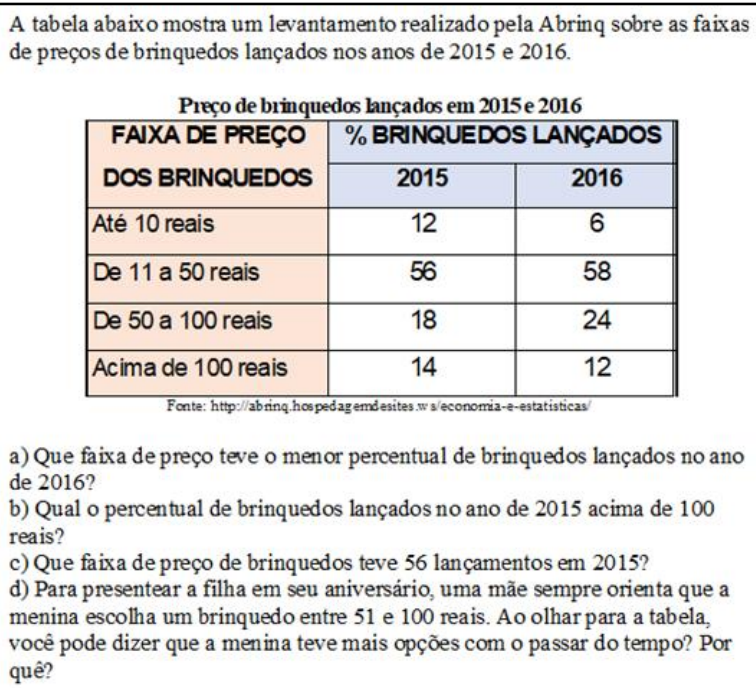

Figure 7. Question 4: Interpretation in double entry table with quantitative interval variable. [Survey conducted by Abrinq on price ranges of toys launched in 2015 and 2016.]

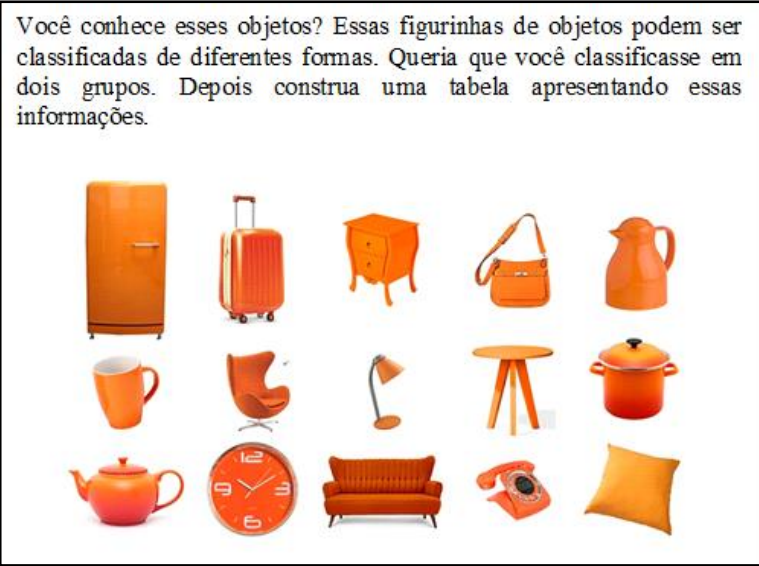

Figure 9. Question 6: Building a single table. Source: Cabral (2016)

[Do you know these objects? These object stickers can be classified in different ways. I would like you to classify in two groups. Then, build a table presenting this information.]

The test was conducted in the classroom and during normal class periods, and data were collected between May and July 2018. In each class, the students solved the problems proposed individually, taking 1 hour 30 minutes, on average. One of the researchers, who is a teacher of this level of education, conducted the activity, reading the questions one at a time, as there were students in different phases of reading mastery.

Besides the construction of the questions, data analysis was structured based on the categories identified in the various studies presented earlier in this text. Initially, we classified the answers given by students as correct or incorrect, based on the criteria set out in the questions. For this, a student's score could vary between 0 and 20 points, depending on the number of correct answers obtained. 
In the first four questions, which involved interpretation of data in tables, one point per correct item was awarded. For items (a), it was considered correct to place the value of the smallest cell. For items (b), it was correct to identify the correct frequency of a category. For items (c), the question was the opposite of the previous question, therefore, correct to identify a category based on a frequency. For items (d), there could be different answers, as it was requested that the student who, based on the data in the table, gives a conclusion and justify it. In this item, the justification was fundamental, and any answer based on the data was considered correct.

In the last two questions, which explored the ability to construct tables, the score could range from 0 to 2 points for each question. In Question 5 (Figure 8), one point per table that displayed one of the variables (gender or medals) or two points per table with both variables was awarded. In Question 6 (Figure 9), one point per classification that met the exclusivity and completeness criteria and another point per table constructed that represented the data systematized from the classification previously performed were awarded.

To verify the potential improvement of students' knowledge, the analysis of variance (ANOVA), which considers the average of correct answers between school grades, was carried out.

\section{RESULTS AND DISCUSSION}

The results from the diagnostic test performed with students from different school grades is presented in Table 1. This table shows the average hits, or correct responses, for each of the school grades. It is observed that student performance is better due to schooling, as expected. According to the Analysis of Variance (ANOVA), there is an important difference in function of school grades $[F(320$, $4)=53.372 ; p \leq 0.000]$. To find out whether this difference occurred between all grades, the Tukey post-test was conducted, showing a significant difference $(p \leq 0.000)$ between the grades, except between the 2nd and 3rd grades, where the significance is $p=0.05$, and the little difference perceived between the 4 th and 5 th grades $(p=0.816)$.

Table 1: Average hits per school grade

\begin{tabular}{cc}
\hline School grade & Average hits \\
\hline 1st & 6.23 \\
2nd & 9.13 \\
3rd & 10.72 \\
4th & 12.81 \\
5th & 13.41 \\
\hline
\end{tabular}

Thus, schooling was an important factor for student performance, corroborating the studies by Martí et al. (2010), Conti and Carvalho (2011), and Diefenthäler and Avi (2016) that had already stated that knowledge on tables is only acquired through formal teaching situations that lead students to reflect on their matrix organization, the data represented, and the necessary elements for construction.

After presenting the overall performance, we proceeded to analyze each question. Figure 10 shows the percentages of student success per grade/question. In all questions, since the 1 st grade, we find some students were able to answer correctly. An improvement in student performance as a function of schooling for all issues was also evidenced. Figure 10 also shows that students performed better on questions of interpretation (Questions 1 through 4) than on construction questions (Questions $5 \& 6$ ). The studies by Lôbo and Alcântara (2011) and Fernandes (2014) showed that students also performed better on issues involving interpretation of tables. 


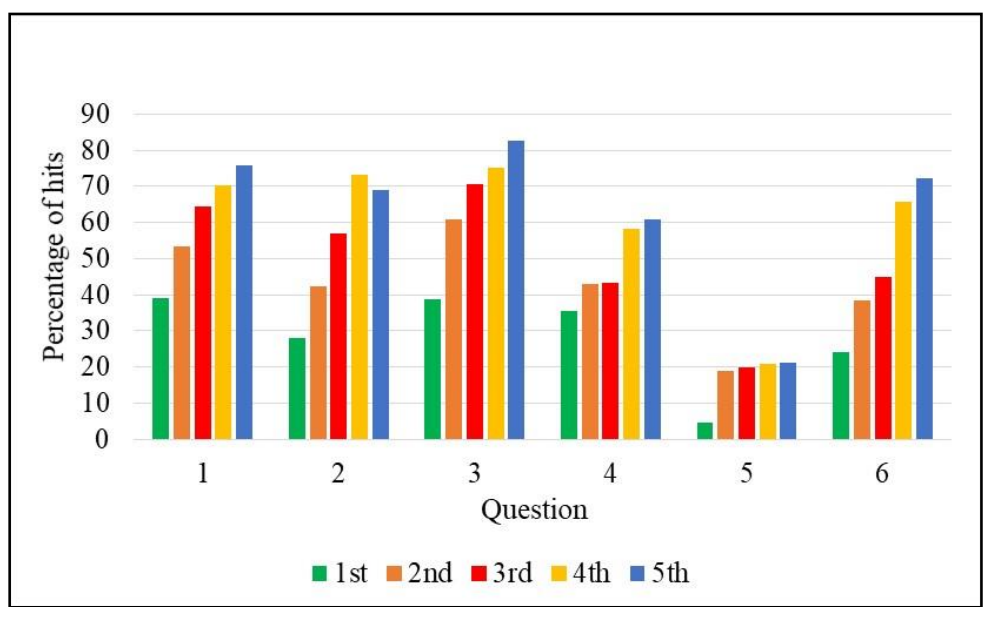

Figure 10. Percentage of hits (correct answers) per question and grade level

The percentages of correct answers in single table questions (Questions 1 \& 2) are similar for all grades of schooling. The same does not occur in relation to the questions that present a double entry table (Questions 3 \& 4). Questions 1 and 3 involve a nominal variable, while Questions 2 and 4 involve an interval variable. Thus, we believe that students' underperformance in Question 4 may be due to the combination of table type (double entry) and variable type (interval numeric). This potential relationship needs to be further investigated in future studies.

Brazilian curriculum prescriptions (BNCC, 2017) state that "Reading and interpreting information represented in single tables" (p. 280) must occur from the 1st grade on. Our data show the possibility of children from these grades to understand that representation and there is a great improvement of such understanding with schooling. Regarding "Reading and interpreting information represented in double entry tables" (p. 288), the document stated that it should happen from the 3rd grade on. However, our results show that the 1st grade $37 \%$ of students answered the questions correctly, and that, from the 2nd grade on, more than $50 \%$ of students get them correct.

We now consider it important to analyze performance by considering each of the questions explored (minimum cell location, frequency, category, and decision making) as each investigated a different skill. Figure 11 shows the percentages of student successes in the four types of data interpretation questions in tables by grade level.

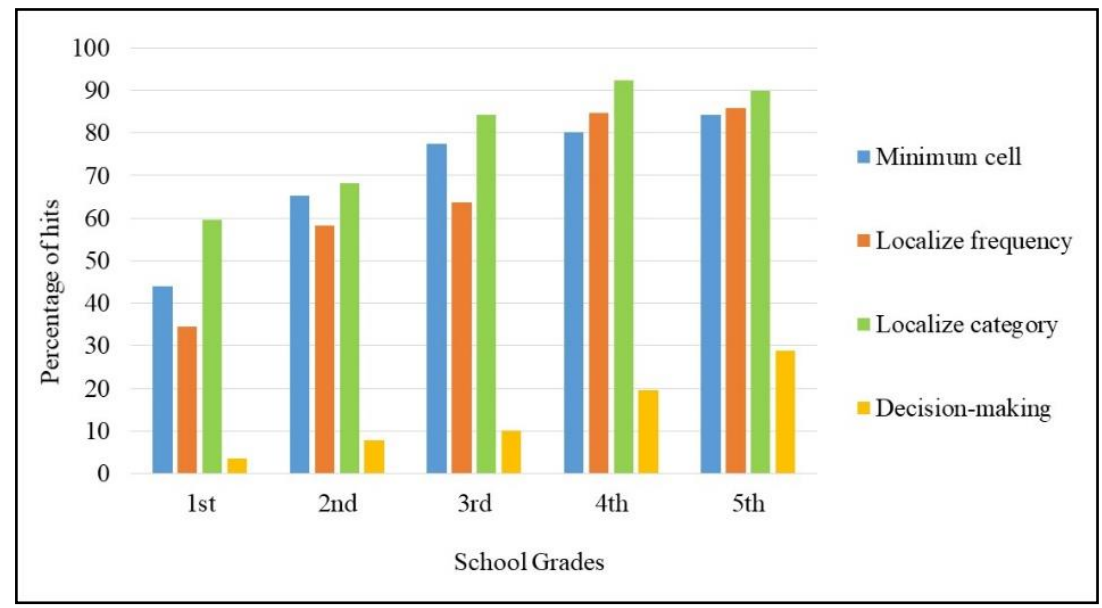

Figure 11. Percentage of correct answers on interpretation questions by grade level.

It was observed that as schooling progressed, the percentage of correct answers in each grade increased for all types of questions explored in the interpretation questions, showing that students can identify information between the intersection of rows and columns. The results, however, of the 5th 
graders show a slight decrease when compared to the 4th grade. Another point observed was that few students could relate to the data and reach a conclusion or make decisions, which is the fundamental purpose of this representation. Thus, it seemed that neither school nor life experience had been enough to support students to understand the function of a table. This result was also found with 7th grade students, who were unable to make predictions and inferences about data in statistical tables, as shown by Nope et al. (2015).

Faced with the situations presented in the questions, students gave personal answers from their life experiences (e.g., Because I like it; it's my team; it's what I chose; you can learn; it's dangerous, the shark ...."), ignoring the data contained in the systematized information presented. We also found that students, after the 1 st grade, were able to use the data in the tables to justify their decisions. In addition, increased performance between grades of schooling is evident. For Silva and Guimarães (2013), it was considered important that children of the early grades to have contact with different types of graphical representations, so that they can choose and understand the best data visualization.

The absence of teaching that has the graph function as a focus can partially explain students' difficulties with the subject. In fact, a reading involving analysis of all data in a related form in a table has been explored little in Brazilian textbook collections, as evidenced by Evangelista and Guimarães (2017; 2019). This causes concerns, because, since the PCNs (Brazil, 1997), it has been argued that "understanding and making decisions in the face of issues of physical and social reality also depend on [students'] reading and interpreting complex, contradictory information that includes statistical data and indexes released by the media" (Brasil, 1997, p. 25).

Figure 12 presents the percentage of success of the two questions on construction of tables. Question 5 (Figure 8), which involved constructing a table from a two-variable database, showed the lowest performance for all school grades. As well, learning did not improve along the schooling process. Given these results, it was important to analyze the responses used by students (Table 2) to understand the knowledge they demonstrated through their answers.

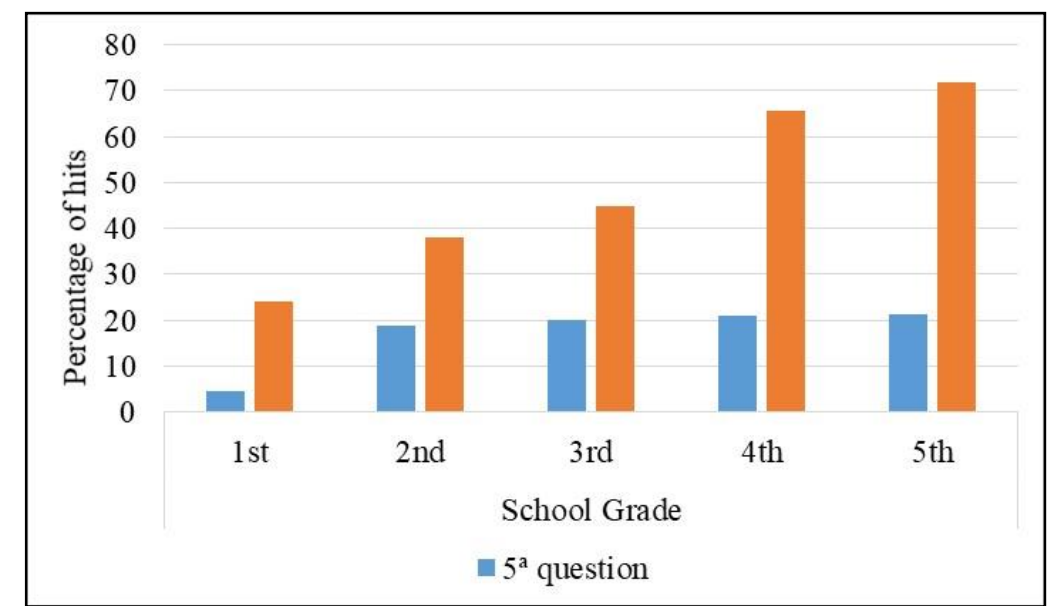

Figure 12. Percentage of successful answers on the construction of tables per grade.

Table 2: Percentage by type of response in Question 5 by school grade

\begin{tabular}{|c|c|c|c|c|c|}
\hline \multirow{2}{*}{ Answer type } & \multicolumn{5}{|c|}{ School grade (\%) } \\
\hline & $1 s t$ & $2 n d$ & $3 r d$ & $4 t h$ & 5 th \\
\hline Did not answer the question & 10.6 & 4.7 & 1.7 & 4.5 & 4.4 \\
\hline $\begin{array}{l}\text { Made other types of representations (listing, drawing } \\
\text { and others) }\end{array}$ & 80.3 & 57.7 & 58.4 & 53.8 & 51.6 \\
\hline $\begin{array}{l}\text { Made a table with one variable, putting some elements } \\
\text { (title and descriptor name) }\end{array}$ & 9.1 & 37.6 & 39.9 & 40.2 & 44 \\
\hline $\begin{array}{l}\text { Made a table with two variables by naming the } \\
\text { descriptors }\end{array}$ & 0 & 0 & 0 & 1.5 & 0 \\
\hline
\end{tabular}


Most of the students used other types of representations, such as listing, drawing, database copy, among others (Figure 13), especially in the 1st grade. Increasingly with schooling, some students built a single table (Figure 14) in which they presented only one of the variables. Only one 4th grade student built a double entry table.

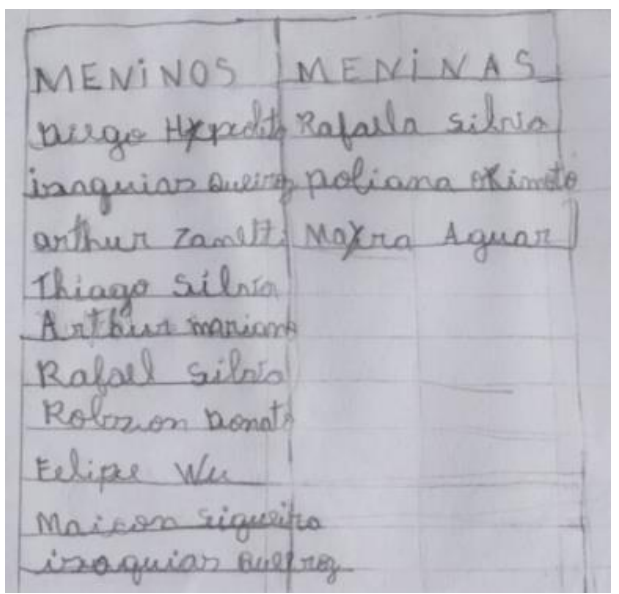

Figure 13. Makes a lint divided by gender. [Student 4.11]

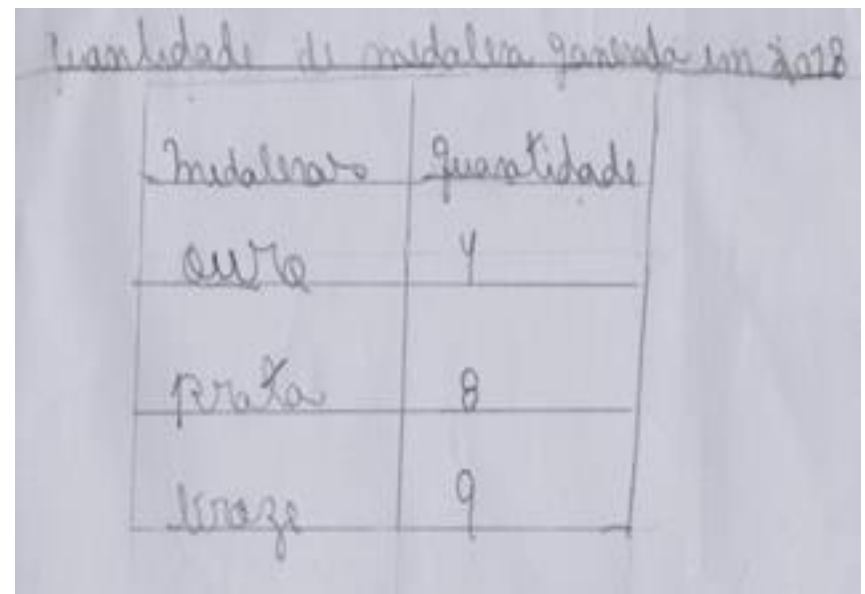

Figure 14. Construction of a single table with only one year. [Student 4.15]

In Question 6 (Figure 9), involving classifying a group of elements and building a table from this classification of raw data, the performance increased, with the percentage of correct answers of the 4th and 5th graders being $66 \%$ and $72 \%$, respectively. Thus, it is explicit that building a double entry table was the greatest difficulty found in this diagnosis.

Because Question 6 involved two distinct skills-sorting raw data and constructing tables, we analyzed the types of strategies students used considering both skills (Table 3). It was possible to verify that several students from the 1st to the 3rd grade could not classify data, only making the figures available in groups and naming them after one of them (Figure 15). This type of strategy was found by Guimarães (2002), Luz and Guimarães (2010), Cabral and Guimarães (2019) and Cabral (2016). Students from all grades used more than one criterion simultaneously for classification. In fact, as Cabral (2016) analyzed, the students in this study ended up separating data by groups of the same property, but not organizing them according to a criterion (Figure 16). This type of strategy was also seen in the study reported by Cabral (2016) and Cabral and Guimarães (2019).

Table 3: Percentage by type of classification in Question 6 by school grade

\begin{tabular}{lccccc}
\hline \multicolumn{1}{c}{ Answer type } & \multicolumn{4}{c}{ School grade (\%) } \\
\cline { 2 - 6 } & lst & 2 nd & 3rd & 4 th & 5th \\
\hline Does not classify, just splits elements into groups. & 39.4 & 14.1 & 13.4 & 0.0 & 0.0 \\
Classifies incorrectly, because they use more than & 13.6 & 23.2 & 25.0 & 20.9 & 4.4 \\
one criterion & 0.0 & 0.0 & 1.7 & 0.0 & 0.0 \\
Classifies elements into three groups/classes & 47.0 & 62.5 & 60.0 & 79.1 & 95.6 \\
Classifies correctly & & & & &
\end{tabular}




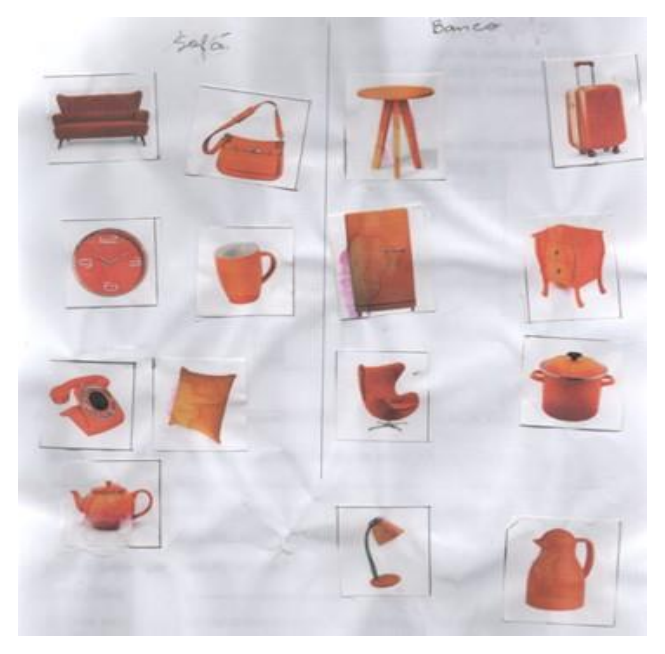

Figure 15. Split the elements spatially and names the group by one of the couch and bench elements. [Student 1.01]

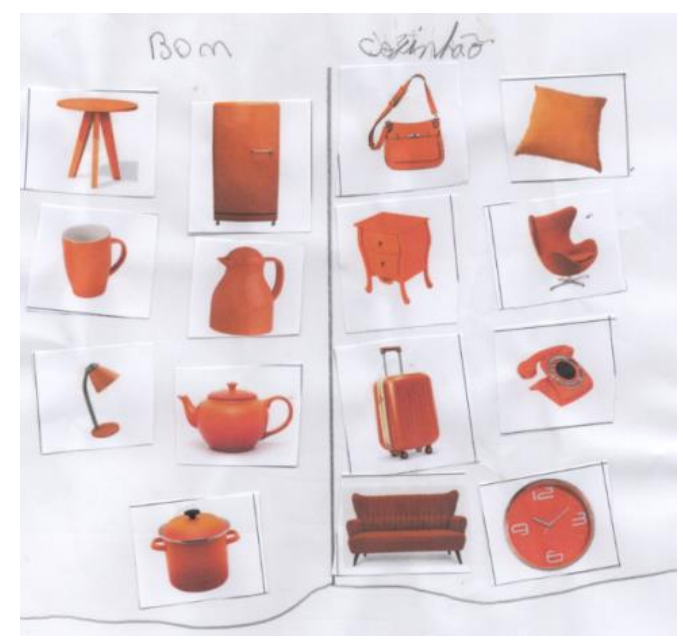

Figure 16. Used more than one criterion: Object quality (good) and where it can be found in a home (kitchen). [Student 3.12].

As we had expected, we found several correct classifications in all grades. In the 1st grade, we found that $47 \%$ of the students answered correctly. This percentage increased with schooling, up to the 5th grade, when almost all students answered the questions correctly (95.6\%). In Figures 17 and 18 we present examples in which students group the elements according to the places where objects are found in a house (the living room and the kitchen) or because of the flexibility of the raw material, whether it is hard or fluffy.

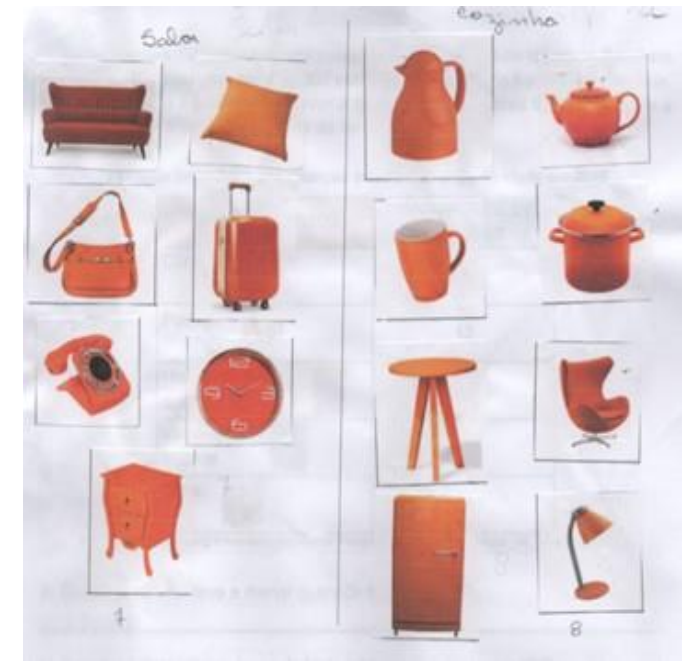

Figure 17. Correct classification with criterion: where it can be found in a home (living room or kitchen). [Student 2.46]

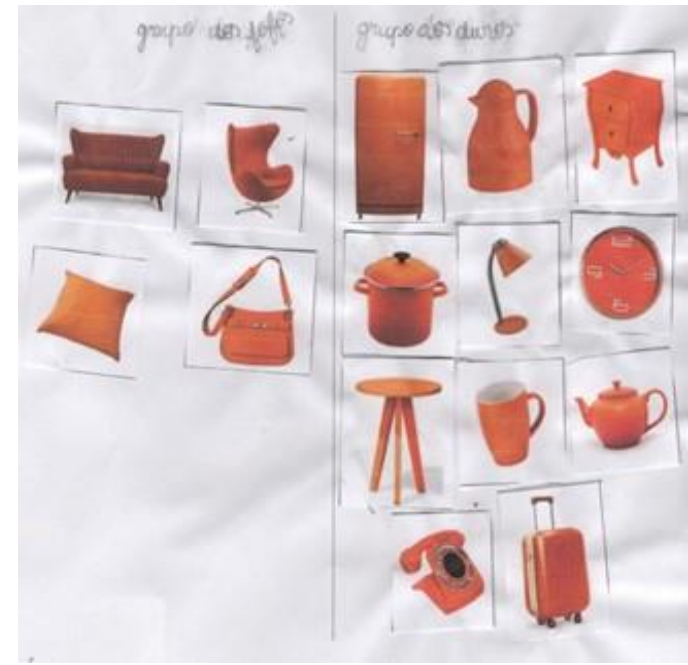

Figure 18. Correct classification with criteria: raw material flexibility (hard or fluffy). [Student 2.40]

Once we have analyzed the types of classification strategies found in Question 6, we present the types of table construction carried out by the students for Question 5 (Table 4). The low performance in the construction of decreasing-form tables as a function of schooling was observed. Although most students classified the data, they found it very difficult to construct the table from those data. Some students wanted to construct a table, but they misrepresented it. In Figure 19, we present a student who classified "thing of the living room and thing of the kitchen" correctly, however, putting the classes on top of each other, ignoring the columns, despite registering the quantities in columns. As well, the student left aside several rows. 
Table 4: Percentage by strategy type when constructing a table in Question 5 by school grade

\begin{tabular}{lccccc}
\hline \multirow{2}{*}{ Answer type } & \multicolumn{5}{c}{ School grade (\%) } \\
\cline { 2 - 6 } & 1 st & 2 2nd & 3 rd & 4 th & 5 th \\
\hline Did not build table & 97.0 & 82.8 & 51.7 & 44.8 & 38.3 \\
Made tables with misrepresentations & 0.0 & 0.0 & 6.7 & 0.0 & 5.9 \\
Made the table but did not quantify the elements & 0.0 & 0.0 & 10.0 & 3.0 & 0.0 \\
Made the table without title and name of variables & 3.0 & 17.2 & 30.0 & 52.2 & 39.7 \\
Made a table & 0.0 & 0.0 & 1.6 & 0.0 & 16.1 \\
\hline
\end{tabular}

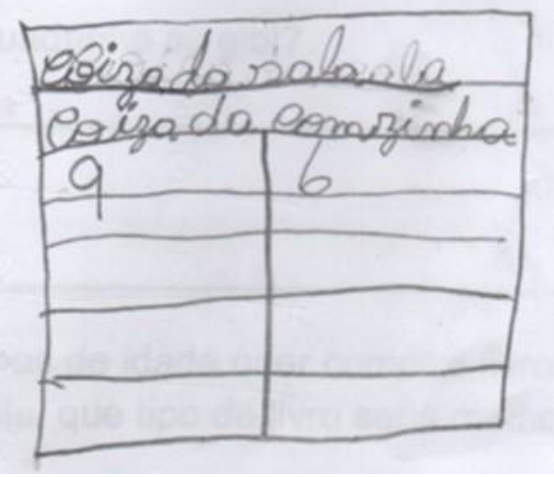

Figure 19. Classified correctly (living room and kitchen things) but overlapped registers. [Student 3.08]

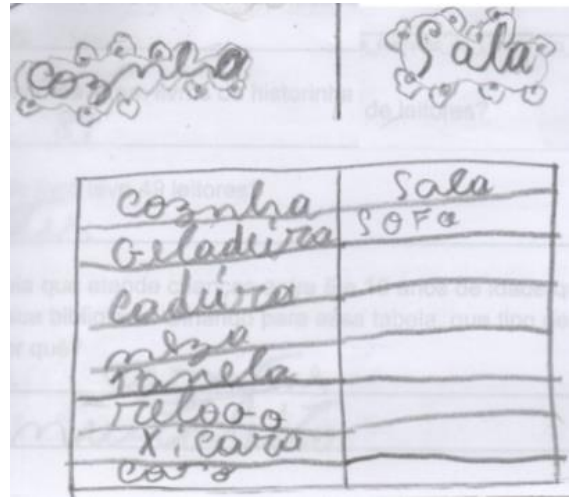

Figure 20. Classified correctly and built a database listing kitchen and living room objects. [Student 3.16]

None of the 1st or 2nd grade students completed the table construction correctly. In the 3rd and 4th grades, several students responded correctly, but only in the 5th grade did they build the table and include all the elements of this representation, such as the title and descriptors. In the study by Bivar and Selva (2013), this type of difficulty was also observed in the tables constructed by students of the 3rd and 5th grades of elementary school.

In Figure 20, we present an example of a student who made a database. As for the table constructs that we considered as correct, we found two types. In the first type, the students made tables, but did not enter the title and/or the name of the variables (Figure 21). This kind of response was found in all grades, with higher incidence in the 4th year. Bivar and Selva (2013) also noted the absence of some elements such as title and descriptor in students' productions. Finally, in the last category we present students who made the table by placing all the elements of the representation as title and variable name (Figure 22). In this category, we had low percentage correct, being observed only in the 3rd and 5th years.

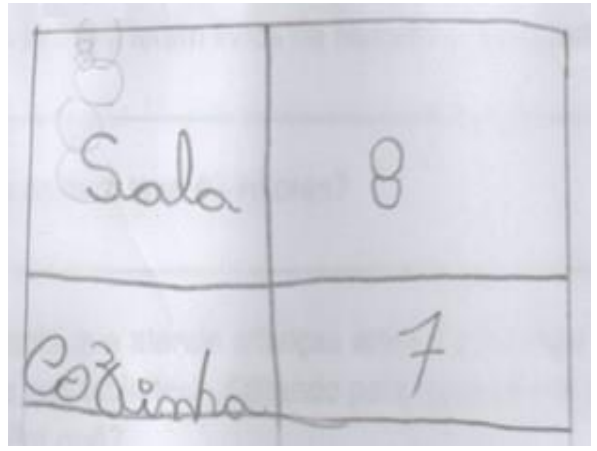

Figure 21. The table has no title and variable name. [Student 2.33]

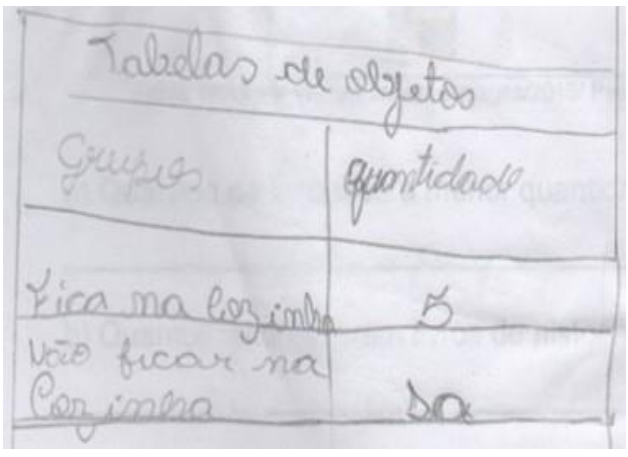

Figure 22. Correct table. [Student 5.54] 
Comparing our results with what is prescribed by BNCC (Brazil, 2017), we observe that, although in the 1st grade the student is expected to be able to "Collect, organize information and represent it through personal records", $24 \%$ of 1 st graders who participated in our study were already able to "Collect, classify, and represent data in single tables with data for categorical variables" (p. 284), which is prescribed only from the 2 nd grade on. As previously presented, this understanding improves with schooling.

On the other hand, "Collecting, classify, and representing data in double-entry tables with data referent to categorical and numerical variables" (p. 294) is prescribed in BNCC for the $4^{\text {th }}$ grade, which we found to be still difficult for the students at that level of education. In the 5th grade, $21 \%$ of the students could respond properly.

\section{CONCLUSIONS}

In this study, we aimed to analyze what students from 1st to 5th grade of public elementary schools know about representations in tables. To this end, we devised a diagnostic test consisting of six questions, four on interpretation of data displayed in single and double entry tables and two on construction of tables from different supports.

For the elaboration of the diagnostic test, we considered what has been proposed in the Brazilian textbooks recommended by the 2016 PNLD (Evangelista \& Guimarães 2017; 2019), and what has been proposed by the Brazilian curriculum and studies that seek to discuss and reflect on importance of teaching tables as a learning focus (Martí et al., 2010; Lobo \& Alcântara, 2011; Estrella, 2014; Estrella \& Mena-Lorca, 2014; Guimarães \& Oliveira, 2014; Sepúlveda et al., 2018; Evangelista \& Guimarães, 2017).

Overall, we observed important differences in relation to students' performance according to school grades. This can be explained by the cognitive development of the students and/or the teaching that has been done in the classroom. These results are very encouraging, because they indicate that from the 1st grade on, we found some students were able to answer correctly, thus showing school has been fulfilling its educational role. Learning to understand the representation of data in tables is critical for students to understand the physical and social world around them and the school is demonstrating its relevance, since life experience is not enough for that.

We also observed that students were able to identify specific information present at the intersection of rows and columns of a table. However, when asked to relate all the data in the questions that involved decision making, they found it to be very difficult. This was regardless of the school grade and, when responding, the students generally referred to their life experiences. However, to be able to make decisions based on what the data indicates, it is necessary that the situations are real and likely to be understood in terms of the target audience. With the advance of schooling, more and more students should be led to reflect on information in tables presented in the most diverse modes of scientific dissemination and in the media, in general. This type of activity requires students to list all the data to conclude what the data indicate and then, be able to make decisions based on the data. As stated by Gal (2002), people often make decisions based on their beliefs rather than being based on data. However, Albuquerque (2019) stated that if students are encouraged to reflect on the actual data, exposing their ideas and contrasting with their beliefs, they can understand the importance of analyzing what the data has to say.

Constructing a table from a database was the most difficult activity for the students. Some students could not distinguish a database from a table. Evangelista and Guimarães (2017) observed that the math textbooks of the early grades do not refer to a database representation in any activity. However, we consider it important to understand the difference between a database and a table, as they express different information and require different comprehension skills from the students. Another difficulty found in the question involving the passage from a database to a table was to build a double-entry table, since the construction of a single table was performed by several students. Since the Brazilian curriculum prescribes that students must learn to build a double-entry table, it is important that future studies investigate the possibility for students to learn to differentiate a database from a table and to learn to construct double-entry tables, by coordinating two variables.

Our results show that the type of table and the type of variable influence the performance of students from 1st to 5th grade of elementary education when building tables. Future studies could investigate 
whether these difficulties are age-related cognitive misunderstandings or whether more systematic work by teachers in schools is needed.

Thus, teachers need to lead students to understand how a table is structured, reflecting on how to classify the data into different variables or understand the variables created by others, the importance of the title and the source to be clarified and questioned about their pertinence, to finally understand how the data represented relate to each other. In addition, students should be encouraged to justify their conclusions and decision-making based on the data represented in the table, realizing that their beliefs can be reviewed based on the data.

\section{REFERENCES}

Albuquerque, M. (2019). Escala apresentada em gráficos: conhecimentos matemáticos para o ensino dos anos iniciais do Ensino Fundamental (crianças e Eja). [Scale presented in graphs: Mathematical knowledge for the teaching of the initial years of elementary education] [Doctoral dissertation, Universidade Federal de Pernambuco].

Amorim, N., \& Guimarães, G. (2017). Teaching statistics in textbooks: The PNLD and the teacher's handbook. In Proceedings of International Conference on Mathematics Textbook Research and Development (pp. 326-334). http://www.sbembrasil.org.br/files/ICMT2017.pdf

Amorim, N., \& Guimarães, G. (2016). Estatística nos anos iniciais: o currículo prescrito nos guias do PNLD [Statistics in early years: the curriculum prescribed in the PNLD guides]. Anais do $X$ Encontro Nacional de Educação Matemática [ENEM].

http://www.sbembrasil.org.br/enem2016/anais/pdf/7007_3134_ID.pdf

Amorim, N., \& Silva, R. (2016). Apresentação e utilização de tabelas em livros didático de Matemática do $4^{\circ}$ E $5^{\circ}$ anos do Ensino Fundamental [Presentation and use of tables in Mathematics textbooks of the 4th and 5th years of Basic Education]. Revista de Educação Matemática e Tecnologia Iberoamericana [EM TEIA], 7(1). https://periodicos.ufpe.br/revistas/emteia/article/view/3893

Bianchini, D., \& Nehring, C. (2013). Práticas estatísticas de professoras dos anos iniciais - uma discussão preliminar. [Statistical practices of teachers from early years: A preliminary discussion] Anais do XI Encontro Nacional de Educação Matemática [ENEM]. Curitiba. http://sbem.iuri0094.hospedagemdesites.ws/anais/XIENEM/pdf/232_169_ID.pdf

Bivar, D., \& Selva, A. (2013). Como as crianças constroem tabelas? [How do children build tables?] Anais do $3^{\circ}$ SIPEMAT - Simpósio Internacional de pesquisa em Educação Matemática, Ilhéus. http://proativa.virtual.ufc.br/sipemat2012/papers/600/submission/director/600.pdf

Bivar, D., \& Selva, A. (2011). Analisando atividades envolvendo gráficos e tabelas nos livros didáticos de matemática. [Analyzing activities involving charts and tables in math textbooks] Anais da XIII CIAEM - Conferência Interamericana de Educação Matemática. https://ciaemredumate.org/ocs/index.php/xiii_ciaem/xiii_ciaem/paper/view/1332/843

Brasil. (1997). Parâmetros Curriculares Nacionais [National Curricular Parameters]. $1^{\mathrm{a}}$ a $4^{\mathrm{a}}$ série, Ministério da Educação, Secretaria de Educação Fundamental - Brasília: MEC/SEF.

Brasil. (2015). Guia de livros didáticos: PNLD 2016: Alfabetização Matemática e Matemática [Textbook guide: PNLD 2016: Mathematical and mathematical literacy]. Secretaria de Educação Básica, MEC.

Brasil. (2017). Base Nacional Comum Curricular [Common National Curricular Base]. Brasília: Ministério da Educação, MEC. Versão Final. http://basenacionalcomum.mec.gov.br/

Cabral, P. (2016). Aprender a classificar nos anos iniciais do Ensino Fundamental. [Learning to classify in the early years of Elementary Education] [Doctoral dissertation, Universidade Federal de Pernambuco] https://attena.ufpe.br/handle/123456789/2228

Cabral, P., \& Guimarães, G. (2019). Aprendizagem sobre classificação nos anos iniciais do Ensino Fundamental [Learning about classification in the initial years of primary education]. Revista Eletrônica de Educação, 13(1), 211-231.

http://www.reveduc.ufscar.br/index.php/reveduc/article/view/2091

Cazorla, I., Magina, S., Gitirana, V., \& Guimarães, G. (2017). Estatística para os anos iniciais do Ensino Fundamental. [Statistics for the initial years of basic education] Sociedade Brasileira de Educação Matemática (SBEM). http://www.sbem.com.br/files/ebook_sbem.pdf 
Conti, K., \& Carvalho, D. (2011). O letramento presente na construção de tabelas por alunos da Educação de Jovens e Adultos. [The reading present in the construction of tables by students of the education of young people and adults] Boletim de Educação Matemática, 24(20), 637-658. http://www.redalyc.org/pdf/2912/291222113002.pdf

Curi, E., \& Nascimento, J. (2016). O trabalho com gráficos e tabelas nos currículos prescritos, apresentados, praticados e avaliados. [The work with charts and tables in the curricula prescribed, presented, practiced and ecaluated] ENCEPAI - Encontro de Combinatório, Estatísticas e Probabilidade dos anos iniciais. http://anaisencepai.edumatec.net/index.php/2016-02-24-19-4428/comunicacoes-cientificas/item/o-trabalho-com-graficos-e-tabelas-nos-curriculos-prescritosapresentados-praticados-e-avaliados

Dessbesel, R., \& Cury, H. (2013). Uma análise do ensino de Estatística ministrado por professores da Educação Básica no município de Cruz Alta. [An analysis of the teaching of Statistics given by teachers of Basic education in the municipality of Cruz Alta] VII CIBEM - Congreso Iberoamericano de Educación Matemática, Montevideo (pp. 5650-5657).

Díaz-Levicoy, D., Morales, R., \& Ortiz, C. (2017). Construcción de tablas estadísticas por estudiantes chilenos de tercero de Educación Primária. [Construction of statistical tables by Chilean students in the third grade of Primary Education] Educação \& Linguagem, 20(1), 149-66. http://funes.uniandes.edu.co/10617/

Diefenthäler, A., \& Avi, E. (2016). Trabalhando conceitos estatísticos a partir de uma gincana: o Papel do professor como mediador de processos investigativos. [Working statistical concepts from a gincana: The role of the teacher as mediator of investigative processes] In Encontro Nacional de Educação Matemática. http://www.sbembrasil.org.br/enem2016/anais/pdf/5991_3007_ID.pdf

Duval, R. (2003). Comment analyser le fonctionnement représentationnel des tableaux et leur diversité? [How to analyse the representation function of tables and their diversity?] SPIRALE - Revue de Recherches en Éducation, 32, 7-31. https://www.persee.fr/doc/spira_09943722_2003_num_32_1_1377

Estrella, S. (2014). El objeto tabla: un estudio epistemológico, cognitivo y didáctico. [The table object: An epistemological, cognitive and didactic study] [Doctoral dissertation, Pontificia Universidad Católica de Valparaíso]

Estrella, S., \& Mena-Lorca, A. (2014). Vergnaud's theory applied to basic school students' statistical representations. In K. Makar, B. de Sousa, \& R. Gould (Eds.), Sustainability in Statistics Education. Proceedings of the Ninth International Conference on Teaching Statistics, Flagstaff, July 13-18. https://iaseweb.org/icots/9/proceedings/pdfs/ICOTS9_C251_ESTRELLA.pdf

Estrella, S., Mena-Lorca, A., \& Olfos, R. (2017). Naturaleza del objeto matemático "Tabla". [Nature of the mathematical object "Table"] Magis, Revista Internacional de Investigación en Educación, 10(20), 105-122. https://doi.org/10.11144/Javeriana.m10-20.nomt

Evangelista, B., \& Guimarães, G. (2017). Tables in textbooks for elementary school grades 4 and 5. II International Conference on Mathematics Textbook Research and Development (ICMT), Rio de Janeiro. Anais do II ICMT.

Evangelista, B., \& Guimarães, G. (2019). Análise de atividades sobre tabelas em livros didáticos brasileiros dos anos iniciais do Ensino Fundamental. [Analysis of activities on tables in Brazilian textbooks of the initial years of Fundamental Education] Tercer Congreso International Virtual de Educación Estadística. Actas del Tercer Congreso International Virtual de Educación Estadística. https://www.ugr.es/ fqm126/civeest/evangelista.pdf

Febles, M., \& Guerra, A. (2009). Un estudio sobre la competência de los alumnos en el manejo de tablas para resolver situaciones cotidianas. [A study on the competence of students in the handling of tables to solve everyday situations] In M. J. González, M. T. González, \& J. Murillo (Eds.), Investigación en Educación Matemática XIII (pp. 227-236). SEIEM.

Fernandes, G., \& Junior, S. (2014). O ensino e aprendizagem de gráficos e tabelas para os anos iniciais do ensino fundamental. [The teaching and learning of charts and tables for the initial years of primary education] Congreso Iberoamericano de Ciencia, Tecnología, Innovación y Educación, Buenos Aires.

Francisco, V. (2014). Interpretação de tabelas por alunos da eja: uma análise sob a pespectiva do letramento estatístico. [Interpretation of tables by eja students: An analysis under the weighing of statistical reading] Anais do $V$ Encontro de pesquisa educacional em Pernambuco - EPEPE. 
https://www.fundaj.gov.br/images/stories/epepe/V_EPEPE/EIXO_3/VALDIRRAMOSFRANCIS CO-CO03.pdf

Gal, I. (1996). Assessing students' interpretations of data: conceptual and pragmatic issues. In B. Phillips (Ed.), Papers on Statistical Education presented at ICME-8, International Congress on Mathematics Education-8, Seville, Spain, July 14-21.

Gal, I. (2002). Adults' statistical literacy: Meanings, components, responsibilities. International Statistical Review, 70(1), 1-25.

Giot, B., \& Quittre, V. (2008). Les tableaux à double entrée dans les écrits scientifiques des jeunes élèves [The double-entry tables in the scientific writings of young students]. Cahiers des Sciences de l'Éducation. https://orbi.uliege.be/bitstream/2268/13232/1/GIOT_QUITTRE_CAH2728_2008_103.pdf

Gitirana, V. (2014). A pesquisa como eixo estruturador da Educação Estatística [Research as the structural axis of Statistical Education]. In BRASIL: Pacto Nacional pela Alfabetização na Idade Certa (pp. 7-20). Caderno 7 (Educação Estatística). Brasília: Ministério da Educação. https://www.pomerode.sc.gov.br/arquivos/SED/2016/MA/PNAIC_MAT_Caderno_7_pg001_080. pdf

Guimarães, G. (2002). Interpretando e Construindo Gráficos de Barras [Interpreting and building bar charts] [Doctoral dissertation, Universidade Federal de Pernambuco] https://repositorio.ufpe.br/handle/123456789/8222

Guimarães, G. (2009). Categorização e representação de dados: o que sabem os alunos do Ensino Fundamental. [Categorization and representation of data: What students in elementary school know] In R. Borba, \& G. Guimarães (Eds.). A pesquisa em educação matemática: Repercussões na sala de aula, Cortez.

Guimarães, G., \& Gitirana, V. (2013). Estatística no Ensino Fundamental: a pesquisa como eixo estruturador. [Statistics in fundamental education: Research as a structural axis]. In R. Borba, \& C. Monteiro (Eds.), Processos de ensino e aprendizagem em Educação Matemática. UFPE.

Guimarães, G., \& Oliveira, I. (2014). Construção e interpretação de gráficos e tabelas. [Construction and interpretation of charts and tables] In Brasil: Pacto Nacional pela Alfabetização na Idade Certa, Caderno 7 (pp. 21-38). (Educação Estatística).

https://www.pomerode.sc.gov.br/arquivos/SED/2016/MA/PNAIC_MAT_Caderno_7_pg001_080. pdf

Guimarães, G., Gitirana, V., Cavalcante, M., \& Marques, M. (2007). Livros didáticos de Matemática nas séries iniciais: Análise das atividades sobre gráficos e tabelas. [Mathematics textbooks in early grades: Analysis of activities on charts and tables] Anais do IX Encontro Nacional de Educação Matemática. Belo Horizonte, July 18-21. https://1library.org/document/yerl2n0q-didaticosmatematica-series-iniciais-analise-atividades-graficos-tabelas.html

Indicador Nacional de Alfabetismo Funcional. (2011). Principais resultados. Ação Educativa. http://acaoeducativa.org.br/wp-content/uploads/2011/10/informe-de-resultados_inaf2011.pdf

Indicador Nacional de Alfabetismo Funcional. (2016). Estudo especial sobre alfabetismo e mundo do trabalho. Ação Educativa.

https://drive.google.com/file/d/0B5WoZxXFQTCRRWFyakMxOTNyb1k/view

Jungkenn, M., \& Del Pino, J. (2009). Analisando a capacidade de estudantes concluintes do ensino fundamental de interpretar informações de gráficos e tabelas. [Analyzing the ability of elementary school students to interpret chart and table information] VII Empec - Encontro Nacional de Pesquisa em Educação em Ciências, Florianópolis.

Lima, R., \& Viali, L. (2013). Os registros semióticos mobilizados por alunos da eja na interpretação de dados em representações tabulares e gráficas. [Semiotic records mobilized by EJA students in interpreting data in tabular and graphical representations] In IV Congresso Internacional de Ensino da Matemática, Ulbra, Canoas.

http://www.conferencias.ulbra.br/index.php/ciem/vi/paper/view/1173

Lôbo, F., \& Alcântara, L. (2011). Analisando a construção e a interpretação de gráficos e tabelas por estudantes do Ensino Médio Regular e EJA [Analyzing the construction and interpretation of charts and tables by regular high school and EJA students]. Anais da XIII CIAEM - Conferência Interamericana de Educação Matemática, Recife.

http://www.lematec.net.br/CDS/XIIICIAEM/artigos/2216.pdf 
Luz, P., \& Guimarães, G. (2010). Classificações nos anos iniciais do ensino fundamental: o papel das representações [Classifications in the initial years of primary education: The role of representations]. Anais do $X$ Encontro Nacional de Educação Matemática, Salvador. http://www.lematec.net.br/CDS/ENEM10/artigos/CC/T3_CC1191.pdf

Martí, E., Sedanio, E., \& La Cerda, C. (2010). Alfabetización gráfica: La apropiación de las tablas como instrumentos cognitivos. [Graphic literacy: Appropriation of tables as cognitive instruments] Contextos, Años IX and X (10), 65-78.

Nope, Á., Bernal, J., \& Alfonso, I. (2015). El pensamiento crítico en la interpretación de tablas y gráficos estadísticos en el aula. [Critical thinking in the interpretation of statistical tables and graphs in the classroom] In J. M. Contreras, C. Batanero, J. D. Godino, G. R. Cañadas, P. Arteaga, E. Molina, M. M. Gea, \& M. M. López (Eds.), Didáctica de la Estadística, Probabilidad y Combinatoria 2, Granada (pp. 239-24). http://www.estadis.net/3/actas/Actas\%20de\%20las\%202\%20Jornadas\%20Virtuales.pdf

Oliveira, P., \& Guimarães, G. (2012). Provinha Brasil de matemática: uma análise de itens e descritores de estatística por professores dos anos iniciais. [Coming from Brazil of mathematics: An analysis of items and descriptors of statistics by teachers of the initial years] Anais do $3^{\circ}$ Simpósio Internacional de Pesquisa em Educação Matemática, Fortaleza.

Pagan, A., Fonseca, S., \& Magina, S. (2013). O nível do letramento estatístico em alunos de diferentes áreas de formação. [The level of statistical reading in pupils from different training areas] Anais do VII Congresso Iberoamericano de Educação Matemática, Montevideo. http://cibem.semur.edu.uy/7/actas/pdfs/60.pdf

Pereira, R., \& Conti, K. (2011). O Tratamento da Informação Presente em Livro Didático de Matemática do $5^{\circ}$ Ano do Ensino Fundamental. [The treatment of information in the mathematics textbook of the 5th year of elementary education] Revista Técnico-Científica das Faculdades Atibaia, V1.

Pfannkuch, M., \& Rubick, A. (2002). An exploration of students' statistical thinking with given data. Statistics Education Research Journal, 1(2), 4-21.

Santos, L. (2016). Representação em tabela: compreensão de professores dos anos iniciais acerca do ensino aprendizagem. [Table representation: understanding teachers from early years about learning education] Anais do XX Encontro Brasileiro de Estudantes de Pós-Graduação em Educação Matemática, Curitiba.

http://www.ebrapem2016.ufpr.br/wpcontent/uploads/2016/04/gd1_luanna_santos.pdf

Sepúlveda, A., Díaz-Levicoy, D., \& Jara, D. (2018). Evaluación de la comprensión sobre Tablas Estadísticas en estudiantes de Educación Primaria [Assessment of understanding of statistical tables in primary education students]. Bolema, Rio Claro (SP), 32(62), 869-886. http://dx.doi.org/10.1590/1980-4415v32n62a06

Sharma, S. (2013). Assessing students' understanding of tables and graphs: Implications for teaching and research. International Journal of Educational Research and Technology, 4(4), 51-70. http://soeagra.com/ijert/ijertdecember2013/10f.pdf

Silva, E., \& Guimarães, G. (2013). Perspectivas para o ensino da educação estatística. [Prospects for the education of statistical education] In Encontro Nacional de Educação Matemática. Anais do XI ENEM, Curitiba.

Wild, C., \& Pfannkuch, M. (1999). Statistical thinking in empirical enquiry. International Statistical Review, 67(3), 223-265.

http://www.stat.auckland.ac.nz/ iase/publications/isr/99.Wild.Pfannkuch.pdf

BETÂNIA EVANGELISTA

Brasil CEP

Rua Estrada Velha de Água Fria, 908

BL A5 ap 304

Tamarineira Recife - Pernambuco 